\title{
INTELLECTUALEPOLITIA: GOVERNMENT OF THE Intellectuals, But by the People and for People
}

\author{
Siddharth Sharma
}

\begin{abstract}
$\underline{\text { Abstract }}$
In this paper I am going to share the views of Socrates and Frank Herbert about the best government system we have, that is democracy. We will also discuss, why it is failing and how can we develop a system, which doesn't nagates public representation, a key integral aspect of democracy, which ensures the will of the people; yet doesn't let incompetent charismatic leaders at the helm of the system, a key flaw of it. We will call this system "Intellectualepolitia", for the reasons best explained in the paper.
\end{abstract}

\section{Socrates, Herbert and their issues with Democracy}

Plato in his collection of books called Republic, described Socrates highly pessimistic of democracy, to be precise Athenian democracy (as that was the only democratic system known at that time). In the sixth book of the Republic, Plato described a conversation between Socrates and a character called Adeimantus, where Socrates was trying to get him to see the flaws of democracy by comparing a society to a ship. "If you were heading out on a journey by sea", asked Socrates, "who would you ideally want deciding who was in charge of the vessel? Just anyone or people educated in the rules and demands of seafaring?". "The latter of course", said Adeimantus. "So why then", Socrates responds, "do we keep thinking that any old person should be fit to judge who should be a ruler of a country?"

In Socrates' view that voting is a skill and not a random intuition, it needs to be taught, like any other skill and only those who acquire the skill should be allowed to vote. Mind you inSocrates' was not an elitist, he never believed that narrow few should, he only wanted that people who vote should vote carefully and critically.

Socrates feared if people would vote willy-nilly then that would lead democracy to demagoguery, which means political activity or practices that seek support by appealing to the desires and prejudices of ordinary people rather than by using rational argument.

Ancient Athens had painful experience of demagogues, for example, the louche figure of Alcibiades, a rich, charismatic, smooth-talking wealthy man who eroded basic freedoms and helped to push Athens to its disastrous military adventures in Sicily. Socrates knew how easily people seeking election could exploit our desire for easy answers. He asked us to imagine an election debate between two candidates, one who was like a doctor and the other who was like a sweet shop owner.

"The sweet shop owner would say of his rival, 'Look, this person here has worked many evils on you. He hurts you, gives you bitter potions and tells you not to eat and drink whatever you like. He'll never serve you feasts of many and varied pleasant things like I will.' Do you think the doctor would be able to reply effectively? The true answer - 'I cause you trouble, and go 
against your desires in order to help you' would cause an uproar among the voters, don't you think?"

This is no different from the present day situation where many smooth talking shop owners may it be sweet or tea, continue to belittle and win votes over capable doctors and for few times when good doctors somehow come to the helm, there these shop owners leaves no stone unturned to tarnish the image of them to attain power.

Socrates was not alone even Frank Herbet, who revolutionised writing in his genre, was also sceptical of democracy, following are some quotes from his path breaking series of novel Dune.

"Democracy is susceptible to being led astray by having scapegoats paraded in front of the electorate. Get the rich, the greedy, the criminals, the stupid leader and so on ad nauseam."

-Frank Herbert, Chapterhouse: Dune

According to Frank Herbert, democracy, especially representative democracy, is a popularity contest which ensures that the most popular leader wins, but does not guarantee that the leader would be competent, on contrary the system is such it selects only those who are very good at winning a popularity contest, there by the system itself ensures that a Charismatic but incompetant leader comes to power. This is because in the urge of winning an election, the individual may become very good at winning an election, but doesn't give importance to any other skill and since the system rewards such leaders, it is very difficult to have leaders at the helm who can be competent.

The basic fear of Frank Herbert was the same as that of socrates that of democracy leading to demagoguery. Both asked the public to beware of charismatic leaders.

\section{Flaws and Benefits of Democracy}

The most prominent flaw of democracy is high probability of electing a demogurgue at the helm. But there are other flaws too, in most of the countries elections are first past the poll system, leading to a candidate-elect which is not the prominent choice of the majority. Also, Voters tend to vote for a political party instead of a candidate, which leads to a candidate getting elected with compromised integrity. Also, since political parties are non-democratic bodies, hence they tend to give tickets to the candidates who have muscle power or money power instead of the candidates who tend legitimately worth, also this makes it virtually impossible for any individual lacking muscle or money power to get elected as a legislator.

\section{Intellectualepolitia}

Structure Intellectualepolitia is as follows:

1. Intellectual Assembly: It is a group of intellectual people. Anybody who fulfils the minimum requirement automatically becomes it's member. It is divided into different subgroups or subsections, basically on the basis of the field of research, for example political sciences, physical sciences, economics, philosophy, engineering etc. Each subgroup gets further divided into subfields, on the basis of the ministerial requirement, and more the number of ministers in a given field more the number of divisions in that field, for example say there is minister of finance, minister of commerce, minister of corporate affairs etc all this fall under the field of economics, 
so the field would be further divided into these sub fields. The minimum requirements are set on the sub-field, for example, the minimum requirement could be threshold (minimum) h-index for the given sub-field, so that each subfield would have sufficient number of members.

2. Legislature: It is a house of elected representatives, each member is elected through the process of election in which campaigning is designed and financed by election commission with no external campaigning allowed by the candidate, or anyone else. For example there could be an assembly hall in each constituency where debates and speeches of all candidates could be conducted and information about each candidate could be circulated and this could only be the campaigning of the candidate. Also candidates who had received votes less than the threshold votes set by the election commission need to repay campaigning expenditure to the election commission. And no formal political party should either be allowed or entertained by the election commission. This would make sure that any one, rich or poor could stand for election.

Legislatures' role is to appoint the government, check the performance of the government and question it on the public matters. If the government loses the confidence of the legislature, it can be removed by a motion of no confidence passed with a two-third majority. Also no bill becomes a law without being passed by legislature by simple majority. Similarly no bill can become an amendment in the constitution without being passed by legislature with a two-third majority. Most importantly the role of the legislature is to ensure the will of the people is heard.

3. Intellectual Council: It is Highest governing body of the nation. From each field three members are nominated by the intellectual assembly and from those three nominated members legislature selects one per field. This selected body forms the intellectual council. Which then selects ministers from each sub-field forming a council of ministers. Council of ministers are answerable to both the intellectual council and legislature. They are basically responsible for policy formation under the supervision of the Intellectual Council. They also put forward the government's point of view in the legislature.

Basic formation of bills is done by the minister who presents and defends the bill in the legislature and if passed with simple majority by the legislature it goes to the intellectual council which if accepted unanimously becomes a law.

The Intellectual Council can be removed if the legislature passes a no confidence motion with two-third majority.

4. Election Commission: An autonomous body which conducts election of the members of legislature, which finances the election campaign of each individual candidate, and makes sure no extra funding is provided to any candidates. Where campaigns consist of debates of individual candidates, their speeches and their manifestos. All conducted in a chamber of a constituency called the central hall of that constituency, large enough to accommodate all citizens of that constituency. 
Elections are conducted in two phases, in the first phase any one can stand for election and in the second phase the election is conducted between the top two candidates, i.e. the two with highest and second highest number of votes.

The autonomy guaranteed by the members of the election commission are directly elected by the people.

5. Research Quality Measuring Council: An autonomous body measures the quality of research. It is also the body which decides the minimum requirement to become the member of the intellectual assembly for example it decides the thershole h-index in every subfield.

6. Passage of Bill: A bill is formed by a minister, then if passed by a simple majority by the legislature it goes to the intellectual council which then if unanimously agrees it becomes a law.

\section{How Intellectualepolitia solves the problems in Democracy}

It is very simple to see that Intellectualepolitia solves the most prominent problem of democracy, having demogurgue at the helm. By having an intellectual council at the helm, which makes sures that people who specialize in their field. But since the intellectual council is selected by members of legislature, answerable to members of legislature and can be dissolved by a no-confidence motion of members of legislature, who are directly answerable to the people, power remains with the people. Hence, intellectualepolitia severe the basic aim of the paper.

It also solves the problem of first past the poll system, due to which a candidate favoured by only a few gets selected, in the mult candidate system, by adding a second phase of election. By removing the party system and election commission financing and taking care of each candidate's election campaign and making sure that election campaigns are the same for all, making sure the best legislature gets elected.

\section{$\underline{\text { References }}$}

1. Plato. Plato's The Republic. New York :Books, Inc., 1943.

2. Berg-Sørensen, A. Democracy and goodness: A historicist political theory. Contemp Polit Theory 19, 235-238 (2020). https://doi.org/10.1057/s41296-019-00353-9

3. Forestal, J., Philips, M. The masked demos: Associational anonymity and democratic $\begin{array}{lllll}\text { practice. Contemp Polit Theory 19, 573-595 (2020). } & \end{array}$ https://doi.org/10.1057/s41296-019-00368-2

4. Standish, P. Becoming who we are: Politics and practical philosophy in the work of Stanley Cavell. Contemp Polit Theory 19, 239-242 (2020). https://doi.org/10.1057/s41296-019-00354-8

5. Tholen, B. Dirty hands and the fragility of democracy. Contemp Polit Theory 19, 663-682 (2020). https://doi.org/10.1057/s41296-019-00376-2

6. Herbert, Frank. Dune. 40th anniversary ed. New York: Ace Books, 2005.

7. Herbert, Frank. Dune Messiah. New York: Ace Books, 1987. 
8. Herbert, Frank. Children of Dune. Berkley trade paperback ed. New York: Berkley Books, 1982.

9. Herbert, Frank. God Emperor of Dune. New York: Putnam, 1981.

10. The Flaw in Our Democracy J. N. LARNED OCTOBER 1899 ISSUE

11. Elliott, K.J. Against Democracy. Contemp Polit Theory 17, 94-97 (2018). https://doi.org/10.1057/s41296-017-0110-6

12. Weale A. (1999) Introduction: Democracy and Political Theory. In: Democracy. Issues in Political Theory. Palgrave, London. https://doi.org/10.1007/978-1-349-27291-4_1

13. Weale A. (1999) Participation and Representation. In: Democracy. Issues in Political Theory. Palgrave, London. https://doi.org/10.1007/978-1-349-27291-4_5

14. Christiano, Thomas (1996). The Rule of the Many. CO: Westview.

15. Bell, D.A. (2016). The China Model: Political Meritocracy and the Limits of Democracy. Princeton University Press.

16. Khanna, Parag (2017-07-01). "Swiss Direct Democracy + Singapore's Smart Rulers = Direct Technocracy". New Perspectives Quarterly. 34 (3): 40-42. doi:10.1111/npqu.12093. ISSN 1540-5842

17. Landemore, Hélène (2017). "Deliberative Democracy as Open, Not (Just) Representative Democracy". Daedalus. doi:10.1162/DAED_a_00446

18. Harpin, Russell (1999). Liberalism, Constitutionalism, and Democracy. Oxford.

19. Doomen, Jasper (2014). Freedom and Equality in a Liberal Democratic State. Brussels: Bruylant. pp. 88, 101. ISBN 978-2802746232.

20. Raël, Geniocracy. Nova Distribution, 2008.

21. Sitting down with Raelians, awaiting aliens, South Florida Sun-Sentinel. 10 September 2001. Retrieved 6 October 2007.

22. Raelians and Cloning: Are They for Real?, Zenit News Agency. 16 January 2003. Retrieved 25 March 2007

23. Ghasemi, Mehdi. "Paradigms of Postmodern Democracy." Sage Open, 2019, April-June: $1-6$.

24. Haas, Michael (2014). Deconstructing the 'Democratic Peace': How a Research Agenda Boomeranged. Los Angeles, CA: Publishinghouse for Scholars.

25. Willard, Charles Arthur (1996). Liberalism and the Problem of Knowledge: A New Rhetoric for Modern Democracy. University of Chicago Press. ISBN 0226898458, 0226898466. OCLC 33967621 